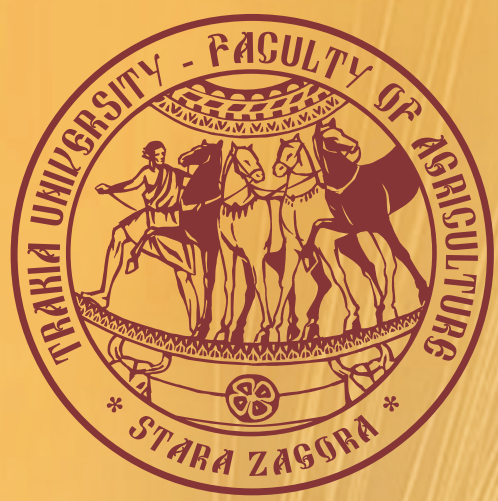

ISSN $1313-8820$ (print)

ISSN 1314 - 412X (online)

Volume 9 , Number 4

December 2017

\title{
AGRICULTURAL
}

\section{SCIENCE AND TECHNOLOGY}

\section{7}

An International Journal Published by Faculty of Agriculture, Trakia University, Stara Zagora, Bulgaria 


\section{Editor-in-Chief}

Georgi Petkov

Faculty of Agriculture

Trakia University, Stara Zagora

Bulgaria

E-mail: gpetkov@af.uni.sz.bg

\section{Co-Editor-in-Chief}

Dimitar Panayotov

Faculty of Agriculture

Trakia University, Stara Zagora

Bulgaria

\section{Editors and Sections}

\section{Genetics and Breeding}

Tsanko Yablanski (Bulgaria)

Atanas Atanasov (Bulgaria)

Svetlana Georgieva (Bulgaria)

Nikolay Tsenov (Bulgaria)

Max Rothschild (USA)

Ihsan Soysal (Turkey)

Horia Grosu (Romania)

Stoicho Metodiev (Bulgaria)

Bojin Bojinov (Bulgaria)

\section{Nutrition and Physiology}

Nikolai Todorov (Bulgaria)

Peter Surai (UK)

Ivan Varlyakov (Bulgaria)

George Zervas (Greece)

Vasil Pirgozliev (UK)

\section{Production Systems}

Radoslav Slavov (Bulgaria)

Dimitar Pavlov (Bulgaria)

Bogdan Szostak (Poland)

Banko Banev (Bulgaria)

Georgy Zhelyazkov (Bulgaria)

\section{Agriculture and Environment}

Martin Banov (Bulgaria)

Peter Cornish (Australia)

Vladislav Popov (Bulgaria)

Tarek Moussa (Egypt)

\section{Product Quality and Safety}

Stefan Denev (Bulgaria)

Vasil Atanasov (Bulgaria)

Roumiana Tsenkova (Japan)

\section{English Editor}

Yanka Ivanova (Bulgaria)
Scope and policy of the journal

Agricultural Science and Technology /AST/

- an International Scientific Journal of Agricultural and Technology Sciences is published in English in one volume of 4 issues per year, as a printed journal and in electronic form. The policy of the journal is to publish original papers, reviews and short communications covering the aspects of agriculture related with life sciences and modern technologies. It will offer opportunities to address the global needs relating to food and environment, health, exploit the technology to provide innovative products and sustainable development. Papers will be considered in aspects of both fundamental and applied science in the areas of Genetics and Breeding, Nutrition and Physiology, Production Systems, Agriculture and Environment and Product Quality and Safety. Other categories closely related to the above topics could be considered by the editors. The detailed information of the journal is available at the website. Proceedings of scientific meetings and conference reports will be considered for special issues.

\section{Submission of Manuscripts}

There are no submission / handling / publication charges.

All manuscripts written in English should be submitted as MS-Word file attachments via e-mail to editoffice@agriscitech.eu. Manuscripts must be prepared strictly in accordance with the detailed instructions for authors at the website

www.agriscitech.eu and the instructions on the last page of the journal. For each manuscript the signatures of all authors are needed confirming their consent to publish it and to nominate on author for correspondence.

They have to be presented by a submission letter signed by all authors. The form of the submission letter is available upon from request from the Technical Assistance or could be downloaded from the website of the journal. Manuscripts submitted to this journal are considered if they have submitted only to it, they have not been published already, nor are they under consideration for publication in press elsewhere. All manuscripts are subject to editorial review and the editors reserve the right to improve style and return the paper for rewriting to the authors, if necessary. The editorial board reserves rights to reject manuscripts based on priorities and space availability in the journal.

The journal is committed to respect high standards of ethics in the editing and reviewing process and malpractice statement. Commitments of authors related to authorship are also very important for a high standard of ethics and publishing. We follow closely the Committee on Publication Ethics (COPE), http://publicationethics.org/resources/guid elines

The articles appearing in this journal are indexed and abstracted in: DOI, EBSCO Publishing Inc., AGRIS (FAO) and DOAJ.

The journal is accepted to be indexed with the support of a project № BG051P00013.3.05-0001 "Science and business" financed by Operational Programme "Human Resources Development" of EU. The title has been suggested to be included in SCOPUS (Elsevier) and Electronic Journals Submission Form (Thomson Reuters).

The journal is freely available without charge to the user or his/her institution. Users can read, download, copy, distribute, print, search, or link to the full texts of the articles, or use them for any other lawful purpose, without asking prior permission from the publisher or the author.

This issue is printed with the financial support by Contract No DNP 0521/20.12.2016, financed from Fund 'Scientific Research' grant Bulgarian scientific Periodicals.

\section{Address of Editorial office:}

Agricultural Science and Technology Faculty of Agriculture, Trakia University

Student's campus, 6000 Stara Zagora

Bulgaria

Telephone: +35942699330 $+35942699446$

www.agriscitech.eu

Technical Assistance:

Nely Tsvetanova

Telephone: +359 42699446

E-mail:editoffice@agriscitech.eu 


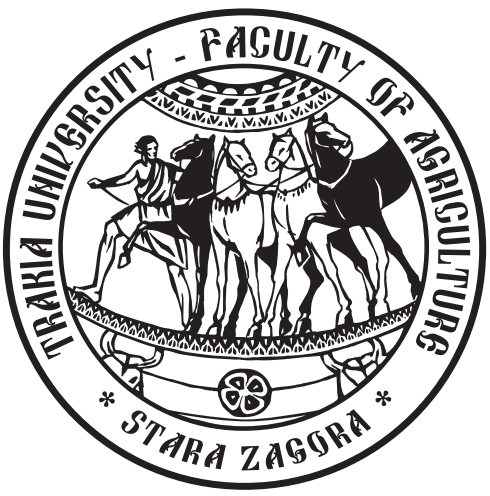

AGRICULTURAL

SCIENCE AND TECHNOLOGY

\section{7}

An International Journal Published by Faculty of Agriculture,

Trakia University, Stara Zagora, Bulgaria 


\title{
Role and importance of the awareness for whey in dairy sector at an international level
}

\author{
M. YıImaz ${ }^{1 *}$, H. Celik², A.D. Karaman ${ }^{3}$, K. Celik ${ }^{4}$ \\ 'Department of Animal Science, Faculty of Agriculture, Adnan Menderes University Aydın, Turkey \\ ${ }^{2}$ Economics and administrative sciences, Çanakkale on Sekiz Mart University, Çanakkale, Turkey \\ ${ }^{3}$ Department of Dairy Technology, College of Agriculture, Adnan Menderes University, Aydın, Turkey \\ ${ }^{4}$ Department of Animal Science, Faculty of Agriculture, Çanakkale on Sekiz Mart University, Çanakkale, Turkey
}

(Manuscript received 6 June 2017; accepted for publication 2 November 2017)

\begin{abstract}
The WHY-WHEY? is a training project supported by the EU with regard to the Erasmus+ program aiming at promoting awareness for it. In this study, the surveys carried out with the participants of a total of 4 workshops in Turkey, Italy, Poland and Hungary were evaluated. Whey is the main dairy by-product, rather than a waste, which is obtained during the coagulation of milk casein in cheese making and which is considered as a residual aqueous solution of lactose containing protein and minerals. Survey results indicated that whey is a significant source and it could facilitate the production of some different alternative products. However, there is a great lack in the knowledge and the awareness in this sense. For this reason, it could be said that more detailed surveys and result analyses could offer a solid base to develop a training course and didactic materials in a way that could completely meet the needs of the sector.
\end{abstract}

Keywords: training project, whey, products, survey, environment protection

\section{Introduction}

The dairy industry is one of the important food industries among all and a major source of waste water and one of the largest sources of industrial effluents in Europe (Britz et al., 2006). A typical European dairy generates approximately $500 \mathrm{t}$ of waste effluent daily. The dairy wastewater usually contains proteins, salt, fatty substances, lactose as well as residues of chemicals used during the cleaning processes. Since the dairy industry produces different products, such as milk, butter, cheese, yogurt, condensed milk, milk powder, ice cream, various types of desserts and cheese, the characteristics of these effluents also vary greatly, depending on the type of the system and the methods of operation used. Among the dairy wastewaters, cheese whey (or whey) has primarily been considered as the most particular waste by the dairy industry. Discovered about 3000 years ago and valued as a medicinal agent in the $17^{\text {th }}$ and $18^{\text {th }}$ centuries, whey, the greenish translucent liquid obtained from milk after precipitation of casein, has recently been viewed as one of the major disposal problems of the dairy industry.

Cheese whey is the main dairy by-product obtained during the coagulation of milk casein in cheese making, which is considered as a residual aqueous solution of lactose containing protein and minerals. Mainly due to the high content in organic compounds, whey exhibits biochemical oxygen demand (BOD) of $30-50 \mathrm{~g} / \mathrm{L}$ and chemical oxygen demand (COD) of $60-80 \mathrm{~g} / \mathrm{L}$. Therefore, the high polluting load of whey and the tremendous growth of dairy industries worldwide constitute its untreated discharge a serious environmental problem (Smithers, 2008). The very substantial polluting powder of whey, with a BOD of some 175 -fold higher level than typical sewage effluent, has, in the recent past, prompted governments and other regulatory authorities to restrict and/or ban the disposal of untreated whey into the nature. About $50 \%$ of the whey produced globally is converted into different food products. Whey is used for the production of citric acid, single-cell proteins, *e-mail: myilmaz@adu.edu.tr lactic acid, ethanol, ethyl lactate, fermented beverages such as kefirlike whey drink, vitamins, biogas, biopolymers, bioplastics etc. These products are commonly used for the production of food, medicine and cosmetics (Smithers, 2008).

It could be a significant benefit if whey could be evaluated as a recycling material and be included into the economic profits of all countries. Although some developed European countries have been using whey for some time, they have been in an effort of searching for newer and more profitable alternative methods. A major contribution to this direction is made by a training project "Improvement of Production and Management Processes in DairyCheese Sector and Dairy Waste Management" (titled as the WHYWHEY?) with participants from 4 countres - Italy, Poland, Hungary and Turkey, supported by the EU with regard to the Erasmus+ program so that the matter could be regarded as a significant one and awareness could be created for it. In this study, the four workshop meetings conducted in Turkey and the surveys for whey carried out by the WHY-WHEY Project participants were evaluated.

\section{Material and methods}

\section{Project participants}

Within the frame of WHY-WHEY? Project training was conducted and the results of the surveys that had been answered by a total of 250 participants from 4 different countries (Italy, Poland, Hungary and Turkey) were evaluated and analyzed together in the workshop meeting in Aydin Province, Turkey. The partisipants were selected according to the dairy sector they represent, the position they hold, their level of activity in the society, and the number of years of experience working in the agro-community. It was sought to identify individuals working on a wide variety of issues from public, private and civic sectors. Active participation took part businessmen, academics, agro-food engineers, veterinarians and medicals. The 
participants were then divided into five groups to discuss on topics and were given a mini questionnaire. Each group had to have participants from different sectors, as well as other stakeholders. Descriptions of participants are given in Table $1(n=250)$. More than half of the participants (50\%) were from research network and between 18 and 25 years of age (40.8\%). The most participants were from Turkey. Many of the participants had college or more than bachelor education degree, $53.2 \%$ of them had $1-10$ years experience in dairy sector.

\section{Survey evaluation}

Seven strategic questions were asked to the participants with presumed answers during the workshops as follow:

- Question-1 (Q1): In your opinion, for what reasons do the farmers, milk producers and cheese makers desire some changes in their products?

- Question-2 (Q2): What kind of innovative approaches can you exemplify in your region with regard to the diary industry byproducts?

- $\quad$ Question-3 (Q3): For which of the innovative approaches you indicated above, do the target groups need training?

- Question-4 (Q4): In your opinion, what kind of complementary management competencies to the technical ones are there in your region? Which one(s) of these is/are the most significant in view of the development of the management competences of the firms in the diary industry sector?

Table 1. Descriptions of project participants $(n=250)$

\begin{tabular}{lr}
\hline \hline Characteristics & $\mathrm{n}(\%)$ \\
\hline Dairy business & \\
Research network & $125(50.0)$ \\
Government authorities & $30(12.0)$ \\
Public authorities & $25(10.0)$ \\
Local committees & $70(28.0)$ \\
Participant age & \\
18-25 years & $102(40.8)$ \\
25-40 & $69(27.6)$ \\
$40-60$ & $42(16.8)$ \\
Older than 60 & $37(14.8)$ \\
Participant countries & \\
Turkey & $100(50.0)$ \\
Italy & $50(20.0)$ \\
Poland & $50(20.0)$ \\
Hungary & $50(20.0)$ \\
Educational level & \\
Graduate of primary school & $32(12.8)$ \\
Graduate of high school & $17(6.8)$ \\
Graduate of primary college & $125(50.0)$ \\
Master or PhD & $76(30.4)$ \\
Dairy sector relation & \\
1-5 years experience in dairy sector & \\
5-10 years experience in dairy sector & $52(20.8)$ \\
More than 10 years experience in dairy sector & \\
Interested in dairy sector & $92(36.8)$ \\
\hline \hline
\end{tabular}

- Question-5 (Q5): Are you of the opinion that the knowledge and training about innovative farming could be easily used in the diary supply chain sector?

- $\quad$ Question-6 (Q6): In your opinion, what kind of a training method do you, female and new farmers prefer?

- Question-7 (Q7): What kind of educational means and activities are more useful for the target groups?

The questionnaire was prepared to determine the educational issues requested by the present and future farmers, milk and cheese producers, the persons and/or bodies wishing to promote their competences in the milk-cheese chain, the ones who desire to increase their production variety and to optimize their activities and their production, and for the professional entrepreneurs related with the diary industry by-products and waste recycling. The survey questions were prepared by determining the status through preliminary research with regard to the general conditions of the countries. Participants of the meetings from every sector were asked to fill in the questionnaire forms (Figure 1).

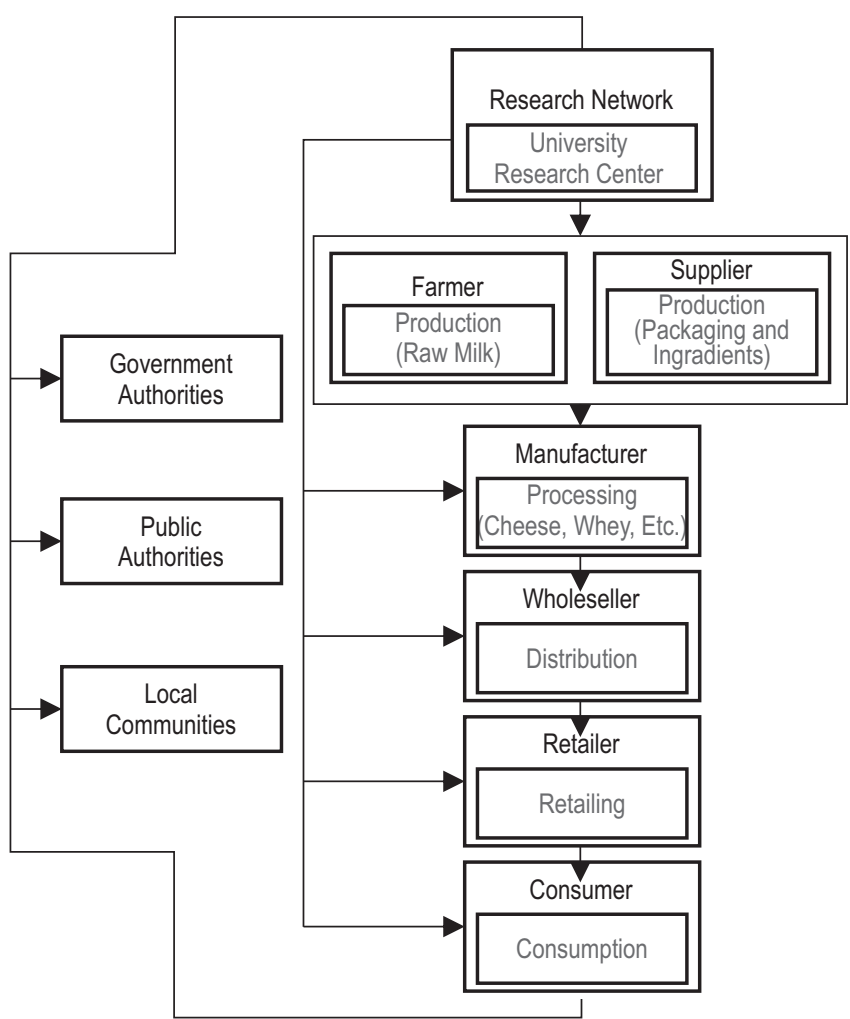

Figure 1. Project participants in workshop in food safety chain in dairy processing

Data analysis

Data in the study conducted was analyzed using Chi-Square test of independence procedure on IBM SPSS 21.

\section{Results}

The general objective of the project was to establish awareness for whey in general and to make it functional. It also aimed specifically to clarify the concept of awareness for whey and how it worked, to clarify what could be benefited by everyone in the whey sector, to identify the bottlenecks about why things did not work/happen, to come up with solutions and dairy strategies on how to overcome the challenges, to come up with clear actions and 
commitments for everyone and to agree on the way forward. During the project presentation, some useful information about whey types, its composition and its nutritional value was reported to the participants. Cheese and whey production in Turkey was also summarized in the presentation. As a general rule, about $9 \mathrm{~L}$ of whey is obtained for every $\mathrm{kg}$ of cheese produced. According to the rule, data on whey was calculated using the data on cheese production in Turkey and given in Table 2. According to the data, cheese production was $539560 \mathrm{t}$ and $574325 \mathrm{t}$ in 2012 and 2013, respectively. Approximately 5 million tons of whey per year was released into the nature in Turkey (TUIK, 2014).

Table 2. Cheese production in Turkey (TUIK, 2012-2014)

\begin{tabular}{|c|c|c|c|c|c|c|}
\hline & \multicolumn{3}{|c|}{ Cheese made from cow's milk, $\mathrm{t}$} & \multicolumn{3}{|c|}{ Cheese made from sheep, goat, buffalo and mixed milk, $t$} \\
\hline & 2012 & 2013 & 2014 & 2012 & 2013 & 2014 \\
\hline January & 43395 & 45766 & 49018 & 2429 & 2292 & 2316 \\
\hline February & 44558 & 45401 & 48977 & 2219 & 2281 & 2565 \\
\hline March & 43861 & 47212 & 49831 & 1751 & 2186 & 2602 \\
\hline April & 44203 & 48057 & 48851 & 1591 & 2152 & 2633 \\
\hline May & 44606 & 48205 & 47561 & 1910 & 2036 & 2884 \\
\hline June & 44045 & 48028 & 49875 & 1780 & 2332 & 2632 \\
\hline July & 45920 & 48735 & 48535 & 2265 & 1967 & 2856 \\
\hline August & 45746 & 47977 & 49290 & 2258 & 2178 & 2825 \\
\hline September & 46591 & 47014 & & 2507 & 2110 & \\
\hline October & 45643 & 48731 & & 2179 & 2220 & \\
\hline November & 44765 & 49642 & & 2070 & 2347 & \\
\hline December & 46227 & 49557 & & 2026 & 2394 & \\
\hline Total Cheese & 539560 & 574325 & 391938 & 24985 & 26495 & 21313 \\
\hline TOTAL WHEY & 4856040 & 5168925 & 3527442 & 224865 & 238455 & 191817 \\
\hline
\end{tabular}

When it comes to European countries, Italy is one of the most striking examples where the quantity of milk collected, the cheese produced and the whey is released as seen in Tables 3, 4 and 5 (EUROSTAT, 2014).

Table 3. Annual data of cows' milk collected in some Europian countres, thousand tons (Eurostat, 2014)

\begin{tabular}{lrrr}
\hline \hline & 2009 & 2010 & 2011 \\
\hline Italy & 10560 & 10408 & 10260 \\
Turkey & - & - & 7074 \\
Hungary & 1407 & 1322 & 1308 \\
Romania & 978 & 901 & 892 \\
Greece & 684 & 688 & 638 \\
\hline \hline
\end{tabular}

Table 4. Annual production of cheese in EU and some Europian countres, thousand tons (Eurostat, 2014)

\begin{tabular}{lrrr}
\hline \hline & 2006 & 2009 & 2012 \\
\hline EU-28 & $\mathrm{C}$ & - & 9347 \\
EU-27 & $\mathrm{C}$ & - & 9315 \\
Italy & 1154 & 1178 & 1204 \\
Greece & 182 & 203 & 199 \\
Romania & 71 & $\mathrm{C}$ & $\mathrm{C}$ \\
Hungary & 57 & 75 & $\mathrm{C}$ \\
\hline \hline
\end{tabular}

$*_{c}$ - confidential
Table 5. Annual data of whey released in EU and some Europian countres, thousand tons (Eurostat, 2014)

\begin{tabular}{lrrr}
\hline \hline & 2006 & 2009 & 2012 \\
\hline EU-28 & - & - & 84123 \\
EU-27 & - & - & 83835 \\
Italy & 10386 & 10602 & 10836 \\
Greece & 1638 & 1827 & 1791 \\
Romania & 639 & - & - \\
Hungary & 513 & 675 & - \\
\hline \hline
\end{tabular}

The answers given by the participants in each workshop conducted in each country are given in Tables 6-12. Participants from different countries showed similarities and differences due to their economical and educational development levels as well as regional and national requirements and their priorities.

The results in Table 6 show that for the answer (a), to get more profitable and higher income, the favored answers from the most to least according to the countries were from Turkey, Poland, Hungary and Italy. The answer (c), to diversify and to fix their income, was given by Italy and Poland. The answer (e), to provide better lives for their relatives, was preferred by Turkey and Hungary and the answer (g), to provide better living conditions, was adopted by Turkey, Hungary and Poland. Chi-Square analysis, which indicates the independence of the answers that the countries gave, show that there is a statistically meaningful relation $(p<0.05)$ between the countries and the answers they gave.

In Table 7, the results show that participants from Turkey, Poland and Hungary mentioned the option (a), to make cheese, using whey as by-product. Besides this choice, the participants from 
Table 6. Results with participant answers to Question 1 - for what reasons do the farmers, milk producers and cheese makers desire some changes in their products?

\begin{tabular}{|c|c|c|c|c|c|c|c|}
\hline & & & \multicolumn{4}{|c|}{ Country } & \multirow{2}{*}{ Total } \\
\hline & & & Italy & Turkey & Poland & Hungary & \\
\hline \multirow{10}{*}{ Variant } & \multirow{3}{*}{ a } & Count & 37 & 72 & 44 & 40 & 193 \\
\hline & & $\%$ within Variant & $74.0 \%$ & $72.0 \%$ & $88.0 \%$ & $80.0 \%$ & $77.2 \%$ \\
\hline & & Count & 6 & 0 & 3 & 0 & 9 \\
\hline & \multirow[t]{2}{*}{ c } & $\%$ within Variant & $12.0 \%$ & $0 \%$ & $6.0 \%$ & $0 \%$ & $3.6 \%$ \\
\hline & & Count & 0 & 20 & 0 & 4 & 24 \\
\hline & \multirow[t]{2}{*}{ e } & $\%$ within Variant & $0 \%$ & $20,0 \%$ & $0 \%$ & $8.0 \%$ & $9.6 \%$ \\
\hline & & Count & 7 & 0 & $0 \%$ & 0 & 7 \\
\hline & \multirow[t]{2}{*}{$f$} & $\%$ within Variant & $14.0 \%$ & $0 \%$ & 0 & $0 \%$ & $2.8 \%$ \\
\hline & & Count & 0 & 8 & 3 & 6 & 17 \\
\hline & g & $\%$ within Variant & $0 \%$ & $8.0 \%$ & $6.0 \%$ & $12.0 \%$ & $6.8 \%$ \\
\hline \multirow[b]{2}{*}{ Total } & & Count & 50 & 100 & 50 & 50 & 250 \\
\hline & & $\%$ within Variant & $100 \%$ & $100 \%$ & $100 \%$ & $100 \%$ & $100 \%$ \\
\hline
\end{tabular}

*a - to get more profitable and higher income; c - to diversify and to fix their income; e - to provide better lives for their relatives ; $\mathrm{f}$ - to benefit from European funds; $\mathrm{g}$ - to provide better living conditions.

Table 7. Results with participant answers to Question 2 - what kind of innovative approaches can you exemplify in your region with regard to the diary industry by-products?

\begin{tabular}{|c|c|c|c|c|c|c|c|}
\hline & & & \multicolumn{4}{|c|}{ Country } & \multirow{2}{*}{ Total } \\
\hline & & & Italy & Turkey & Poland & Hungary & \\
\hline & & Count & 0 & 75 & 39 & 34 & 148 \\
\hline & $a$ & $\%$ within Variant & $0 \%$ & $50.7 \%$ & $26.4 \%$ & $23.0 \%$ & $100 \%$ \\
\hline \multirow{6}{*}{ Variant } & & Count & 7 & 0 & 6 & 10 & 23 \\
\hline & $d$ & $\%$ within Variant & $30.4 \%$ & $0 \%$ & $26.1 \%$ & $43.5 \%$ & $100 \%$ \\
\hline & & Count & 26 & 20 & 0 & 6 & 52 \\
\hline & e & $\%$ within Variant & $50.0 \%$ & $38.5 \%$ & $0 \%$ & $11.5 \%$ & $100 \%$ \\
\hline & & Count & 10 & 5 & 5 & 0 & 20 \\
\hline & j & $\%$ within Variant & $50.0 \%$ & $25.0 \%$ & $25.0 \%$ & $0 \%$ & $100 \%$ \\
\hline \multirow{2}{*}{ Total } & & Count & 43 & 100 & 50 & 50 & 243 \\
\hline & & $\%$ within Variant & $17.7 \%$ & $41.2 \%$ & $20.6 \%$ & $20.6 \%$ & $100 \%$ \\
\hline
\end{tabular}

*a - to make cheese using whey as by-product; $d$ - to produce lactose and whey powder; e - to produce buttermilk powder to feed animals; $\mathrm{j}$ - to use whey and wastes as biomass energy.

Hungary, Italy and Poland preferred the option (d), to produce lactose and whey powder. Italy, Turkey and Hungary chose the option (e), to produce buttermilk powder to feed animals. As a last preference, Italy, Turkey and Poland showed preference for the option (j), to use whey and wastes as biomass energy. The result for Chi-Square analysis determinated a statistically meaningful relation $(p<0.05)$ between the answers by participants from different countries.

The participant's answers in Table 8 revealed that participants from Turkey, Poland and Hungary chose the option (a), to make cheese, using whey as by-product. Italy, Turkey and Hungary chose the option (e), to produce buttermilk powder to feed animals. Poland and Hungary showed preference for $(\mathrm{g})$, the usage of some compounds (sugars, fats) and minerals. Poland, Hungary and Turkey, with leading Italy, preferred the option (h), to use whey protein as protein support. In the last part, Hungary and Turkey wanted training for the option (j), to use whey and wastes as biomass energy. Differences in participants' responses are statistically proven at $p<0.05$

The results in Table 9 showed that participants from Turkey indicated answer (a), management and recording, while the ones from Italy, Poland and Hungary mentioned (b), to use European funds (EAFRD, ERDF, ESF). Participants from Turkey, Hungary and Italy showed preference for the option (c), strategic planning and business plan. Turkey and Hungary showed favor for (d), relationships with the banks, while Italy and Poland showed sympathy for (e), relationships with the insurance companies. On the other hand, Hungary, Poland and Turkey chose answer (g), individual marketing strategies and Poland, Italy, Hungary and Turkey chose (h), group marketing strategies. All differences in participants' responses are statistically proven at $p<0.05$.

On the question in Table 10, more of the participants from Turkey $(38.1 \%)$, Italy $(25.0 \%)$ and Hungary $(19.3 \%)$ give a positive answer, while these one from Poland (39.6\%) give negative answer. 
Table 8. Results with participant answers to Question 3 - for which of the innovative approaches you indicated above, do the target groups need training?

\begin{tabular}{|c|c|c|c|c|c|c|c|}
\hline & & & \multicolumn{4}{|c|}{ Country } & \multirow{2}{*}{ Total } \\
\hline & & & Italy & Turkey & Poland & Hungary & \\
\hline \multirow{12}{*}{ Variant } & \multirow{3}{*}{ a } & Count & 0 & 66 & 37 & 24 & 127 \\
\hline & & $\%$ within Variant & $0 \%$ & $52.0 \%$ & $29.1 \%$ & $18.9 \%$ & $100 \%$ \\
\hline & & Count & 0 & 0 & 1 & 0 & 1 \\
\hline & \multirow[t]{2}{*}{$C$} & $\%$ within Variant & $0 \%$ & $0 \%$ & $100 \%$ & $0 \%$ & $100 \%$ \\
\hline & & Count & 10 & 8 & 0 & 4 & 22 \\
\hline & \multirow[t]{2}{*}{ e } & $\%$ within Variant & $45.5 \%$ & $36.4 \%$ & $0 \%$ & $18.2 \%$ & $100 \%$ \\
\hline & & Count & 0 & 0 & 2 & 6 & 8 \\
\hline & \multirow[t]{2}{*}{$g$} & $\%$ within Variant & $0 \%$ & $0 \%$ & $25.0 \%$ & $75.0 \%$ & $100 \%$ \\
\hline & & Count & 33 & 2 & 10 & 10 & 55 \\
\hline & \multirow[t]{2}{*}{$\mathrm{h}$} & $\%$ within Variant & $60.0 \%$ & $3.6 \%$ & $18.2 \%$ & $18.2 \%$ & $100 \%$ \\
\hline & & Count & 7 & 4 & 0 & 0 & 11 \\
\hline & j & $\%$ within Variant & $63.6 \%$ & $36.4 \%$ & $0 \%$ & $0 \%$ & $100 \%$ \\
\hline \multirow{2}{*}{ Total } & & Count & 50 & 80 & 50 & 44 & 224 \\
\hline & & $\%$ within Variant & $22.3 \%$ & $35.7 \%$ & $22.3 \%$ & $19.6 \%$ & $100 \%$ \\
\hline
\end{tabular}

*a - to make cheese using whey as by-product; c - to make cheese using a appendıx Product as a by-product; e - to produce buttermilk powder to feed animals; $\mathrm{g}$ - to use of some compounds (sugars, fats) and minerals; $\mathrm{h}$ - to use whey protein as protein support ; $j$ - to use whey and wastes as biomass energy.

Table 9. Results with participant answers to Question 4 - what kind of complementary management competencies to the technical ones are there in your region?

\begin{tabular}{|c|c|c|c|c|c|c|c|}
\hline & & & \multicolumn{4}{|c|}{ Country } & \multirow[t]{2}{*}{ Total } \\
\hline & & & Italy & Turkey & Poland & Hungary & \\
\hline \multirow{14}{*}{ Variant } & \multirow{2}{*}{ a } & Count & 0 & 44 & 0 & 0 & 44 \\
\hline & & $\%$ within Variant & $0 \%$ & $100 \%$ & $0 \%$ & $0 \%$ & $100 \%$ \\
\hline & \multirow{2}{*}{$b$} & Count & 5 & 0 & 10 & 3 & 18 \\
\hline & & $\%$ within Variant & $27.8 \%$ & $0 \%$ & $55.6 \%$ & $16.7 \%$ & $100 \%$ \\
\hline & \multirow{2}{*}{ C } & Count & 10 & 44 & 0 & 11 & 65 \\
\hline & & $\%$ within Variant & $15.4 \%$ & $67.7 \%$ & $0 \%$ & $16.9 \%$ & $100 \%$ \\
\hline & \multirow{2}{*}{$d$} & Count & 0 & 14 & 0 & 9 & 23 \\
\hline & & $\%$ within Variant & $0 \%$ & $60.9 \%$ & $0 \%$ & $39.1 \%$ & $100 \%$ \\
\hline & \multirow{2}{*}{ e } & Count & 10 & 0 & 11 & 0 & 21 \\
\hline & & $\%$ within Variant & $47.6 \%$ & $0 \%$ & $52.4 \%$ & $0 \%$ & $100,0 \%$ \\
\hline & \multirow{2}{*}{$g$} & Count & 0 & 2 & 2 & 6 & 10 \\
\hline & & $\%$ within Variant & $0 \%$ & $20.0 \%$ & $20.0 \%$ & $60.0 \%$ & $100 \%$ \\
\hline & \multirow{2}{*}{$\mathrm{h}$} & Count & 25 & 20 & 27 & 21 & 93 \\
\hline & & $\%$ within Variant & $26.9 \%$ & $21.5 \%$ & $29.0 \%$ & $22.6 \%$ & $100 \%$ \\
\hline \multirow[b]{2}{*}{ Total } & & Count & 50 & 124 & 50 & 50 & 274 \\
\hline & & $\%$ within Variant & $18.2 \%$ & $45.3 \%$ & $18.2 \%$ & $18.2 \%$ & $100.0 \%$ \\
\hline
\end{tabular}

*a - management and recording; b - to use European funds (EAFRD, ERDF, ESF); c - strategic planning and business plan; $\mathrm{d}$ - relationships with the banks; e - relationships with the insurance companies; $\mathrm{g}$ - individual marketing strategies;

h - group marketing strategies;

The differences observed in the responses of the participants from the different countries are statistically proven $(p<0.05)$.

Regarding the method of training (Table 11) Hungary participants have preferred a one week - course (a), however, Turkey, Italy, Hungary and Poland mentioned practical training spread over several weeks or months (b). Hungary also wanted to make a preference for (c), distant learning- offline lessons on the internet, while Turkey, and Italy marked answer (d), distant learningoffline lessons on the internet. In addition, Poland, Turkey and Italy also indicated (e), learning at the meetings and farm visits. The 
Table 10. Results with participant answers to Question 5 - does the knowledge and training about innovative farming could be easily used in the diary supply chain sector?

\begin{tabular}{|c|c|c|c|c|c|c|c|}
\hline & & & \multicolumn{4}{|c|}{ Country } & \multirow{2}{*}{ Total } \\
\hline & & & Italy & Turkey & Poland & Hungary & \\
\hline \multirow{4}{*}{ Variant } & \multirow{2}{*}{ Yes } & Count & 44 & 67 & 31 & 34 & 176 \\
\hline & & $\%$ within Variant & $25.0 \%$ & $38.1 \%$ & $17.6 \%$ & $19.3 \%$ & $100 \%$ \\
\hline & \multirow{2}{*}{ No } & Count & 6 & 13 & 19 & 10 & 48 \\
\hline & & $\%$ within Variant & $12.5 \%$ & $27.1 \%$ & $39.6 \%$ & $20.8 \%$ & $100 \%$ \\
\hline \multirow{2}{*}{ Total } & & Count & 50 & 80 & 50 & 44 & 224 \\
\hline & & $\%$ within Variant & $22.3 \%$ & $35.7 \%$ & $22.3 \%$ & $19.6 \%$ & $100 \%$ \\
\hline
\end{tabular}

Table 11. Results with participant answers to Question 6 - what kind of a training method do you, female and new farmers prefer?

\begin{tabular}{|c|c|c|c|c|c|c|c|}
\hline & & & \multicolumn{4}{|c|}{ Country } & \multirow[t]{2}{*}{ Total } \\
\hline & & & Italy & Turkey & Poland & Hungary & \\
\hline \multirow{10}{*}{ Variant } & \multirow{2}{*}{$a$} & Count & 0 & 5 & 0 & 6 & 11 \\
\hline & & $\%$ within Variant & $0 \%$ & $45.5 \%$ & $0 \%$ & $54.5 \%$ & $100 \%$ \\
\hline & \multirow{2}{*}{$\mathrm{b}$} & Count & 0 & 51 & 0 & 34 & 85 \\
\hline & & $\%$ within Variant & $0 \%$ & $60.0 \%$ & $0 \%$ & $40.0 \%$ & $100 \%$ \\
\hline & \multirow{2}{*}{ C } & Count & 40 & 10 & 22 & 0 & 72 \\
\hline & & $\%$ within Variant & $55.6 \%$ & $13.9 \%$ & $30.6 \%$ & $0 \%$ & $100 \%$ \\
\hline & \multirow{2}{*}{$d$} & Count & 10 & 14 & 16 & 0 & 40 \\
\hline & & $\%$ within Variant & $25.0 \%$ & $35.0 \%$ & $40.0 \%$ & $0 \%$ & $100 \%$ \\
\hline & \multirow{2}{*}{ e } & Count & 0 & 0 & 12 & 0 & 12 \\
\hline & & $\%$ within Variant & $0 \%$ & $0 \%$ & $100 \%$ & $0 \%$ & $100 \%$ \\
\hline \multirow{2}{*}{ Total } & & Count & 50 & 80 & 50 & 40 & 220 \\
\hline & & $\%$ within Variant & $22.7 \%$ & $36.4 \%$ & $22.7 \%$ & $18.2 \%$ & $100 \%$ \\
\hline
\end{tabular}

*a - a one week- course; b - practical training spread over several weeks or months; c - distant learning- offline lessons on the internet; $d$ - distant learning- offline lessons on the internet; e - learning at the meetings and farm visits.

Table 12. Results with participant answers to Question 7 - what kind of educational means and activities are more useful for the target groups?

\begin{tabular}{|c|c|c|c|c|c|c|c|}
\hline & & & \multicolumn{4}{|c|}{ Country } & \multirow{2}{*}{ Total } \\
\hline & & & Italy & Turkey & Poland & Hungary & \\
\hline \multirow{12}{*}{ Variant } & \multirow{2}{*}{ a } & Count & 45 & 56 & 15 & 10 & 126 \\
\hline & & $\%$ within Variant & $35.7 \%$ & $44.4 \%$ & $11.9 \%$ & $7.9 \%$ & $100 \%$ \\
\hline & \multirow{2}{*}{$b$} & Count & 0 & 3 & 0 & 0 & 3 \\
\hline & & $\%$ within Variant & $0 \%$ & $100 \%$ & $0 \%$ & $0 \%$ & $100 \%$ \\
\hline & \multirow{2}{*}{ C } & Count & 0 & 11 & 8 & 6 & 25 \\
\hline & & $\%$ within Variant & $0 \%$ & $44.0 \%$ & $32.0 \%$ & $24.0 \%$ & $100 \%$ \\
\hline & \multirow{2}{*}{$d$} & Count & 0 & 0 & 0 & 3 & 3 \\
\hline & & $\%$ within Variant & $0 \%$ & $0 \%$ & $0 \%$ & $100 \%$ & $100 \%$ \\
\hline & \multirow{2}{*}{$\mathrm{e}$} & Count & 0 & 10 & 17 & 31 & 58 \\
\hline & & $\%$ within Variant & $0 \%$ & $17.2 \%$ & $29.3 \%$ & $53.4 \%$ & $100 \%$ \\
\hline & \multirow{2}{*}{$f$} & Count & 5 & 0 & 0 & 0 & 5 \\
\hline & & $\%$ within Variant & $100 \%$ & $0 \%$ & $0 \%$ & $0 \%$ & $100 \%$ \\
\hline \multirow{2}{*}{ Total } & & Count & 50 & 80 & 40 & 50 & 220 \\
\hline & & $\%$ within Variant & $22.7 \%$ & $36.4 \%$ & $18.2 \%$ & $22.7 \%$ & $100 \%$ \\
\hline
\end{tabular}

*a - online courses based on learning materials and exercises; b - downloadable and printable course materials for offline courses; $c$ - self-studying and a handbook composed of chapters for pre- lesson; $d$ - to organize video-conferences with students via Skype; e - training by a teacher; $\mathrm{f}$ - the usage of all methods. 
differences in participants' responses are statistically proven at $\mathrm{p}<0.05$.

In terms of appropriate educational means and activities participants from Italy, Turkey, Poland and Hungary preferred online courses based on learning materials and exercises (a) (Table 12). Participants from Turkey have preferred an answer (b) downloadable and printable course materials for offline courses. Participants from Turkey, Poland and Hungary have chosen (c), selfstudying and a handbook composed of chapters for pre- lesson. Participants from Hungary also mentioned answer (d), to organize videoconferences with students via Skype, and the participants from Hungary, Poland and Turkey offered (e), training by a teacher. Italy also added (f), the usage of all methods. Chi-Square analysis revealed that there is a statistically meaningful relation $(p<0.05)$ between the answers by countries.

\section{Discussion}

One of the greatest sectors of the economies in industrialized and developing countries is the diary industry. Cheese commonly forms the primary destinations of milk processing with nearly $45 \%$ of the total milk production, nearly half of the whole volume. As a result of this, approximately $90 \%$ of the milk used in cheese production industry is eliminated as whey, which is the most important byproduct of this process. On the other hand, it is a reality that whey contains about $55 \mathrm{~g} / 100 \mathrm{~g}$ of the total ingredients of milk, such as lactose, soluble proteins, lipids and mineral salts. Owing to the recent data, it is now believed that whey is a significant and valuable product rather than being a waste one (Ha and Zemel, 2003; Jeken, 2003; Sanmartín, 2012) and therefore called 'forgotten treasure' in recent years (Królczyk et al., 2016). However, according to statistics, a significant part of this by-product is thrown away as waste which brings some important hazards to the environment (Aider et al., 2009). This claim is more remarkable with regard to cheese production from caprine milk because caprine cheese production centers are smaller and most of the production is done by using hand-craft methods (Palatnik et al., 2015). The proteins in cheese whey, which are accepted as by-products in the cheese making sector, have perfect nutritional and functional properties. Moreover, they have a great capacity to form films (Chen et al., 1995; Pérez et al., 2002; Javanmard, 2009). Because of the fact that they are edible and biodegradable, using whey proteins to manufacture films has gained a great deal of popularity among producers (Krochta and Mulder-Johnston, 1997; Ramos et al., 2012; Pérez et al., 2014).

Another issue related to this matter is that whey is a by-product of cheese production which is either used mainly for feeding animals or released into the wastewater during the treatment process even though it is rich in valuable components (Rector and Vatai, 2004). The importance of whey proteins as food ingredients or additives is increasing depending on this fact. Whey proteins possess the ability to solve in water. In addition to this property, they can create viscosity, can form gels, can emulsify and facilitate whipping, foaming and aeration. Moreover, they can enhance colour, flavour and texture and can offer numerous nutritional advantages to formulated products (US DEC, 1999).

Whey proteins are generally used to produce more nutritious formulas for infants and food for sports, and additionally they exhibit good film forming capacity. An ideal mechanical resistance and constitution of a good gas barrier at low relative humidity are known to be some of the characteristics of whey protein films (Kurek et al.,
2014) in addition to their being an excellent barrier to aroma compounds and oil (Miller et al., 1998). On the other hand, edible films and coatings are only moderate barriers to moisture because of the fact that whey is a hydrophilic protein. Among them, proteinbased materials seem to be most attractive, since they also provide nutritional benefits (Galus and Kadzińska, 2015). Whey protein is generally used to give resistance support for training athletes because there are rapid absorption kinetics and a high leucine content in whey protein, which makes consumption more profitable to promote muscle protein synthesis (MPS) than other proteins (Hulmi et al., 2010; Pennings et al., 2011).

In addition to these uses, there is increasing evidence that whey protein isolates (WPI) can be utilized to encapsulate and protect bioactive substances, including lactic acid bacteria, depending on their physicochemical characteristics. According to one of the latest researches, during spray drying, WPI has been found to have protective behavior for two strains of Lactobacillus plantarum, A17 and B21 (Pennings et al., 2011).

On the other hand, cheese factories generate great amounts of waste waters and cheese whey (CW) is the most important waste stream produced with high organic content (up to $70 \mathrm{~g} \mathrm{COD/L}$ ) which is highly biodegradable possessing low alkalinity ( $50 \mathrm{meq} / \mathrm{L})$. Since cheese whey is a protein and a lactose-rich by-product of cheese production, its cost-effective utilization or disposal has become increasingly important. If it is discarded untreated into the waterways, cheese whey can cause serious environmental problems due to its high biological oxygen and chemical oxygen demands. As a result, the pollution load from a cheese factory processing $100000 \mathrm{~L}$ of milk per day would be equivalent to the pollution of a city of 60000 inhabitants. Given the large quantity of whey produced worldwide each year, the risks of pollution are therefore extremely high.

On the contrary, recovery of whey components and/or use of whey as fermentation medium could be advantageous not only for the environment but also for a sustainable economy but compared with established west European markets, demand for whey products in the east European and accession countries remains under developed.

Discussion of the results of our study presented in Tables 6-12 revealed the following picture. It was seen in Table 6 that a great majority of the answers to this question for all countries gather around the first choice (a), to get more profitable and higher income, which indicates a general view for more profits and this is a necessity for a better living. When it comes to Table 7, except for Italy, making cheese using whey as a by-product is extremely favoured by the other three countries, by Turkey, the most, by Poland and by Hungary. Although whey could be used to produce various diary byproducts and it has some extra facilities for some other sectors, this answer shows that whey is only known to produce cheese in those countries, and the participants are not fully aware of the additional properties of whey as a profitable by-product. It should not be forgotten that whey is such a potential by-product that could create new markets in various sectors other than cheese production. Table 8 shows that participants from Turkey, Poland and Hungary prefer to be trained for a better usage of whey in cheese making, while Italy is expecting a training course concerning the use of whey protein as protein support. For Table 9, a striking remark should be put here, as the three EU member countries, Italy, Poland and Hungary, in addition to Turkey, preferred group marketing strategies (h), while only Turkey, and to some extent Hungary, declared about the strategic planning (c). Table 10 indicates a result that all participants from all four countries are of the view that the knowledge and training 
for innovative farming is easily accessible. When it comes to the evaluation of Table 11, it could be said that the majority of the participants think they could easily catch up with their gap about the issue through a maximum of a few-month course. In addition, meeting and farm visits are also seen as significant methods. The most crucial analyses of the surveys lie in the evaluation of Table 12 because the participants gave priority to the options of online courses and the ones given by a trainer. Training programs organized and applied by experts in this matter and technological facilities will certainly provide support for the groups from breeders to producers. Therefore, between all results made by Chi-Square analysis for the survey questions, there is a statistically meaningful relation $(p<0.05)$ between the countries and the answers they gave (Tables 6-12). To sum up, training is underlined as the main requirement in milk and dairy sector and for the new enterprises, and particularly informative approaches and methods are concluded to be a must in the evaluation of whey. The questionnaire was split into three sections. The first was dedicated to the most basic questions, such as about age and occupation. The second section was an evaluation of the dairy-whey issue and the third section was dedicated to the evaluation of the downloadable and printable teaching material for an offline course. Without collecting the views of all farmers, milk producers, cheese makers and professionals from milk by-product and waste management in each country, it would be impossible to determine to design a training course and the preparation of educational materials that are responsive to the needs. With regard to the training needs, there are no large differences between the responses collected in the four countries and the indications of respondents would be the guidelines for designing the training contents.

Only in the section "Information and Training Course", the question of whether the respondents think that relevant information and training for innovative agriculture were easily available in the dairy supply chain sector, there were striking differences among the participants' responses. In fact, most respondents in Hungary said that the information was easily available while the respondents from Italy and Turkey replied that they were not. This was the only question that showed significant differences among the countries, and it is expected that the course and didactic materials to be developed could make up for this gap.

\section{Conclusion}

From February to June 2015 the WHY-WHEY? project partners from Italy, Poland, Hungary and Turkey carried out a survey aimed to identify some fields of interest and the appropriate training materials and tools for present and future farmers, milk producers, cheese makers and professionals of the milk by-products and waste management, who are willing to improve their knowledge, skills and competencies in the milk cheese supply chain, to diversify and optimize their activities and products, as well as to develop the management of their businesses. All participants have declared their opinions for the project, and the analyses on the questionnaire prepared by the partners were discussed to determine project requirements after each workshop. After the presentations of the ideas for improvement of the dairy-whey sector, the participants learned about some other projects connected with WHY-WHEY? The participants filled the evaluation questionnaires about the workshop and questionnaire of whey. The questionnaires have been collected in face to face meetings, during dedicated workshops. The questionnaire was split into three sections. The first was dedicated to the most basic questions, such as about age and occupation. The second section was an evaluation of the dairy-whey issue and the third section was dedicated to the evaluation of the downloadable and printable teaching material for offline course. An evaluation of all returned questionnaires of this and of the other workshops was made.

Without collecting the views of all farmers, milk producers, cheese makers and professionals from milk by-product and waste management in each country, it would be impossible to determine to design a training course and the preparation of educational materials that are responsive to the needs. With regard to the training needs, there are no large differences between the responses collected in the four countries and the indications of respondents would be the guidelines for designing the training contents. Only in the section Information and training course, the question of whether the respondents think that relevant information and training for innovative agriculture are easily available in the dairy supply chain sector, there were striking differences among the participants. In fact, most respondents in Hungary said that the information was easily available, while the respondents from Italy and Turkey replied that they were not. This was the only question that shows significant differences among the countries, and the course and didactic materials that will be developed could make up for this gap. General conclusion is that the appropriate surveys and the analyses of the results could offer a solid base to develop a training course and didactic materials in a way that will completely meet the needs of the dairy sector.

\section{Acknowledgements}

The authors wish to thank the project participants for providing the data and the European Committee for supporting this research.

\section{References}

Aider M, Halleux D and Melnikova I, 2009. Skim acidic milk whey cryocon centration and assessment of its functional properties: Impact of processing conditions. Innovative Food Science and Emerging Technologies, 10, 334-341.

Chen H, 1995. Functional properties and applications of edible films made from milk proteins. Journal of DairyScience, 78, 2563-2583.

EUROSTAT, 2014. Annual data of cows' milk collected. http://ec.europa.eu/eurostat/statistics-explained/index.php/ Main_Page

Galus $\mathbf{S}$ and Kadzińska J, 2015. Whey protein edible films modified with almond and walnut oils, Food Hydrocolloids, doi: 10.1016/j.foodhyd.2015.06.013.

Ha E and Zemel M, 2003. Functional properties of whey, whey components, and essential amino acids: mechanisms underlying health benefits for active people (Review). Journal of Nutritional Biochemistry, 14, 251-258.

Hulmi JJ, Lockwood CM and Stout JR, 2010. Effect of protein/essential amino acids and resistance training on skeletal musclehy pertrophy. A case for whey protein. Nutrition and Metabolism, 7, 51.

Javanmard M, 2009. Biodegradable whey protein edible films as new biomaterials for food and drug packaging. Iranian Journal of Pharmaceutical Sciences, 5, 129-134. 
Jelen $\mathbf{P}, 2003$. Whey processing: utilization and products, In: $\mathrm{H}$. Roginski, J. W. Fuquay, and P. F. Fox (Eds.), Encyclopedia of dairysciences, 4, 2739-2745. London: Academic Press (Elsevier Science).

Khem S, Small MD and May BK, 2016. The behaviour of whey protein isolate in protecting Lactobacillus Plantarum. Food Chemistry, 190, 717-723.

Królczyk JB, Dawidziuk T, Janiszewska-Turak E and Sołowiej B, 2016. Use of whey and whey preparations in the food industry - a Review. Polish Journal of Food and Nutrition Sciences, 66, 157-165. Krochta JM and de Mulder-Johnston CD, 1997. Edible and biodegradable polymer films: challenges and opportunities. FoodTechnology, 51, 61-74

Kurek M, Galus S and Debeaufort F, 2014. Surface, mechanical and barrier properties of bio-based composite films based on chitosan and whey protein. Food Packaging and Shelf Life, 1, 56-67. Miller KS, Upadhyaya SK and Krochta JM, 1998. Permeability of d-limonene in whey protein films. Journal of Food Sciences, 63, 244247.

Palatnik DR, Porcel MVO, Gonzalez U, Zaritzky N and Campderros ME, 2015. Recovery of caprine whey protein and its application in a food protein Formulation LWT. Food Science and Technology, 63, 331-338.

Pennings B, Boirie Y, Senden J, Gijsen A, Kuipers H and Van

Loon L, 2011. Whey protein stimulates postprandial muscle protein accretion more effectively than do casein and casein hydrolysate in older men. American Journal of Clinical Nutrition, 93, 997-1005.

Pérez LM, Soazo M del V, Balagué CE, Rubiolo AC and Verdini RA, 2014. Effect of $\mathrm{pH}$ on the effectiveness of whey protein/glycerol edible films containing potassium sorbateto control non-0157 shigatoxin-producing Escherichiacoli in ready-to-eatfoods. Food Control, 37, 298-304.

Pérez-Gago MB and Krochta JM, 2002. Formation and properties of whey protein films and coatings. In A. Gennadios (Ed.), Proteinbased films and coatings, pp. 159-177. New York: CRC Press.

Ramos OL, Fernandes JC, Silva SI, Pintado ME and Malcata FX, 2012. Edible films and coatings from whey proteins: a review on formulation, and on mechanical and bioactive properties. Critical Reviews in Food Science and Nutrition, 6, 533-552.

Rektor A and Vatai G, 2004. Membrane filtration of Mozzarella whey, Desalination, 162, 279-286.

Smithers GW, 2008. Whey and whey proteins - from 'gutter-to-gold'. International Dairy Journal, 18, 695-704.

Sanmartín B, Díaz O, Rodríguez-Turienzo L and Cobos A, 2012. Composition of caprine whey protein concentrates produced by membrane technology alterclarification of cheese whey. Small Ruminant Research, 105, 186-192.

TUIK, 2014. Cheese Production in Turkey http://www.tuik.gov.tr/ US. Dairy Export Council, 1999. Product Specification, Arlington, VA, USA. 


\section{Genetics and Breeding}

Variation in the agronomic and morphological traits in spring barley

N. Dyulgerov, B. Dyulgerova

Study on the loss of accuracy of AC method for milk yield control in sheep

D. Dimov, P. Zhelyazkova, A. Vuchkov

Hordein polymorphism between spring barley cultivars by SDS-PAGE electrophoresis

N. Neykov, S. Doneva

\section{Nutrition and Physiology}

Comparative study of rapeseed, monofloral types and multifloral honey by some physico-chemical parameters

I. Zhelyazkova, S. Lazarov

Body condition score, nonesterified fatty acids and beta-hydroxybutyrate concentrations in goats with subclinical ketosis

V. Marutsova, R. Binev

\section{Production Systems}

Lucrative status of improved dual purpose cowpea (Vigna unguiculata L., Walp) in Damboa, Borno State, North-Eastern Nigeria

B.H. Gabdo

Study on the emptying time of grain harvester hoppers

K. Trendafilov, N. Delchev, B. Kolev, G. Tihanov

Length of the growing season and yield in Triticum monococcum L., in accordance with the growing conditions

S. Stamatov, E. Valchinova, G. Desheva, K. Uzundzhalieva, P. Chavdarov, T. Cholakov, B. Kyosev, R.

Ruseva, N. Velcheva

Productivity of durum wheat cultivar Predel at nitrogen-phosphorous fertilization

L. Plescuta

Effect of the herbicide treatment dose on the weed infestation in common winter wheat

Z. Petrova

Evaluation of some technological properties of Caucasian ram wool

D. Pamukova, G. Staykova, N. Stancheva, D. Panayotov 


\section{Agriculture and Environment}

Saved $\mathrm{CO}_{2}$ emissions by using renewable sources for hot water yield in Bulgarian dairy farms

R. Georgiev, R. Slavov, K. Peychev, D. Georgiev, S. Apostolov, J. Ellingsen, J. Tønnesen

Inventory of the legal base for reclamation of lands disturbed by open-cast mining in Bulgaria

M. Banov, V. Tzolova, I. Kirilov

Taxonomic composition of phytoplankton in Black Sea area in front of the Cape Galata (2008-2016)

D. Klisarova, D. Gerdzhikov

Biodiversity of the macrozoobenthos in some protected marine areas along Bulgarian Black Sea coast

E. Petrova, S. Stoykov

Heavy metals in organs of gudgeon (Gobio gobio L.) from Vardar River, R. Macedonia

R. Nastova, V. Kostov, I. Uslinovska

Product Quality and Safety

Mathematical methods for assessment and analysis of honey yield data for Bulgaria and the

N. Keranova

Carcass traits and meat quality of different slow growing and fast growing broiler chickens

M. Oblakova, N. Mincheva, P. Hristakieva, I. Ivanova, M. Lalev, Sv. Georgieva

Role and importance of the awareness for whey in dairy sector at an international level 


\section{Instruction for authors}

\section{Preparation of papers}

Papers shall be submitted at the editorial office typed on standard typing pages (A4, 30 lines per page, 62 characters per line). The editors recommend up to 15 pages for full research paper ( including abstract references, tables, figures and other appendices)

The manuscript should be structured as follows: Title, Names of authors and affiliation address, Abstract, List of keywords, Introduction, Material and methods, Results, Discussion, Conclusion, Acknowledgements (if any), References, Tables, Figures.

The title needs to be as concise and informative about the nature of research. It should be written with small letter /bold, 14/ without any abbreviations.

Names and affiliation of authors The names of the authors should be presented from the initials of first names followed by the family names. The complete address and name of the institution should be stated next. The affiliation of authors are designated by different signs. For the author who is going to be corresponding by the editorial board and readers, an E-mail address and telephone number should be presented as footnote on the first page. Corresponding author is indicated with *

Abstract should be not more than 350 words. It should be clearly stated what new findings have been made in the course of research. Abbreviations and references to authors are inadmissible in the summary. It should be understandable without having read the paper and should be in one paragraph.

Keywords: Up to maximum of 5 keywords should be selected not repeating the title but giving the essence of study.

The introduction must answer the following questions: What is known and what is new on the studied issue? What necessitated the research problem, described in the paper? What is your hypothesis and goal?

Material and methods: The objects of research, organization of experiments, chemical analyses, statistical and other methods and conditions applied for the experiments should be described in detail. A criterion of sufficient information is to be possible for others to repeat the experiment in order to verify results.

Results are presented in understandable tables and figures, accompanied by the statistical parameters needed for the evaluation. Data from tables and figures should not be repeated in the text. Tables should be as simple and as few as possible. Each table should have its own explanatory title and to be typed on a separate page. They should be outside the main body of the text and an indication should be given where it should be inserted.

Figures should be sharp with good contrast and rendition. Graphic materials should be preferred. Photographs to be appropriate for printing. Illustrations are supplied in colour as an exception after special agreement with the editorial board and possible payment of extra costs. The figures are to be each in a single file and their location should be given within the text.

Discussion: The objective of this section is to indicate the scientific significance of the study. By comparing the results and conclusions of other scientists the contribution of the study for expanding or modifying existing knowledge is pointed out clearly and convincingly to the reader. Conclusion: The most important consequences for the science and practice resulting from the conducted research should be summarized in a few sentences. The conclusions shouldn't be numbered and no new paragraphs be used. Contributions are the core of conclusions. References:

In the text, references should be cited as follows: single author: Sandberg (2002); two authors: Andersson and Georges (2004); more than two authors: Andersson et al.(2003). When several references are cited simultaneously, they should be ranked by chronological order e.g.: (Sandberg, 2002; Andersson et al., 2003; Andersson and Georges, 2004).

References are arranged alphabetically by the name of the first author. If an author is cited more than once, first his individual publications are given ranked by year, then come publications with one co-author, two co-authors, etc. The names of authors, article and journal titles in the Cyrillic or alphabet different from Latin, should be transliterated into Latin and article titles should be translated into English. The original language of articles and books translated into English is indicated in parenthesis after the bibliographic reference $($ Bulgarian $=\mathrm{Bg}$, Russian $=\mathrm{Ru}$, Serbian $=\mathrm{Sr}$, if in the Cyrillic, Mongolian =
Mo, Greek = Gr, Georgian = Geor., Japanese $=\mathrm{Ja}$, Chinese $=\mathrm{Ch}$, Arabic $=\mathrm{Ar}$, etc.)

The following order in the reference list is recommended:

Journal articles: Author(s) surname and initials, year. Title. Full title of the journal, volume, pages. Example:

Simm G, Lewis RM, Grundy B and Dingwall WS, 2002. Responses to selection for lean growth in sheep. Animal Science, 74, 39-50

Books: Author(s) surname and initials, year. Title. Edition, name of publisher, place of publication. Example:

Oldenbroek JK, 1999. Genebanks and the conservation of farm animal genetic resources, Second edition. DLO Institute for Animal Science and Health, Netherlands.

Book chapter or conference proceedings: Author(s) surname and initials, year. Title. In: Title of the book or of the proceedings followed by the editor(s), volume, pages. Name of publisher, place of publication. Example:

Mauff G, Pulverer G, Operkuch W, Hummel K and Hidden C, 1995. C3variants and diverse phenotypes of unconverted and converted C3. In: Provides of the Biological Fluids (ed. $\mathrm{H}$. Peters), vol. 22, 143-165, Pergamon Press. Oxford, UK.

Todorov N and Mitev J, 1995. Effect of level of feeding during dry period, and body condition score on reproductive performance in dairy cows, IX $X^{\text {th }}$ International Conference on Production Diseases in Farm Animals, September 11-14, Berlin, Germany.

Thesis:

Hristova D, 2013. Investigation on genetic diversity in local sheep breeds using DNA markers. Thesis for PhD, Trakia University, Stara Zagora, Bulgaria, (Bg).

The Editorial Board of the Journal is not responsible for incorrect quotes of reference sources and the relevant violations of copyrights.

\section{Animal welfare}

Studies performed on experimental animals should be carried out according to internationally recognized guidelines for animal welfare. That should be clearly described in the respective section "Material and methods". 


\section{AGRICULTURAL \\ SCIENCE AND TECHNOLOGY}

Volume 9, Number 4 December 2017
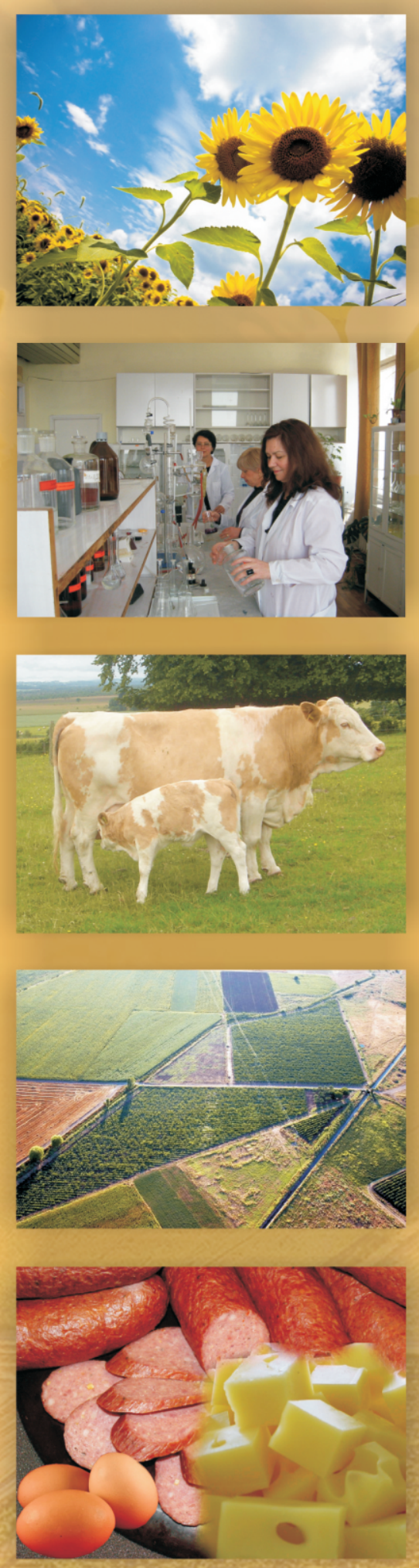

Journal web site: 